\title{
A note on Thysananthus repletus (Lejeuneaceae: Marchantiophyta) with new report on asexual reproduction
}

\author{
Siddhartha Singh Deo \\ Department of Botany, Banwarilal Bhalotia College, Asansol, West Bengal 713 303, India \\ * Email: sidhart29@gmail.com
}

\section{ARTICLE HISTORY}

Received: 06 January 2020

Accepted: 01 February 2020

Published: 01 July 2020

\section{KEYWORDS}

Thysananthus repletus; asexual reproduction; gemmae; West

Bengal; Eastern Himalaya

\section{ABSTRACT}

Specimens of Thysananthus repletus (Taylor) Sukkharak \& Gradstein are collected and described from Alipurduar District of West Bengal in Eastern Himalaya, revealing the presence of asexual reproduction by gemmae on leaf lobe as well as on androecial and gynoecial branches, which is rare for the genus and constitutes the first such report for the species. It is also first report of occurrence of the species from the state of West Bengal. Key to the Indian species of the Thysananthus subg. Mastigolejeunea is provided.

\section{Introduction}

Mastigolejeunea (Spruce) Schiffn. and Thysananthus Lindenb. have been two morphologically similar genera. The two taxa share similar characters such as rigid, thick stems, Lejeunea-type branching, elongate leaf cells, cordate to coalesced trigones, segmented oil bodies, broadly obovate to spathulate, undivided underleaves, gynoecia with 1-2 lejeunoid innovations and 3-keeled perianth. The former is distinguished from the latter by enlarged stem dorsal cortical cells (not enlarged in Thysananthus), entire female bracts and perianth (toothed in Thysananthus) and underleaf bases free, not adnate to leaves (adnate to leaves in Thysananthus). However, few taxa show morphological overlap. T. anguiformis (Hook.f. \& Taylor) Steph. and T. pancheri (Steph.) Hürl. have enlarged dorsal epidermal cells and entire female bracts and bracteoles but underleaves are adnate to leaves and perianth are toothed. Enlarged dorsal epidermal cells also occur in $T$. ciliaris (Sande Lac.) Sukkharak. T. montanus Gradst. et al. is described with entire perianth. Based on the morphological overlaps and molecular analysis of chloroplast and nuclear markers, has been treated Mastigolejeunea as a subgenus of Thysananthus (1).
In the present state of our knowledge, the subgenus is represented by five species from India viz., T. humilis (Gottsche) Sukkharak \& Gradst., T. indicus (Steph.) Sukkharak \& Gradst., T. ligulata (Lehm. \& Lindenb.) Sukkharak \& Gradst., T. repletus (Taylor) Sukkharak \& Gradst., T. virens Ångstr. [all as Mastigolejeunea (2)]. A botanical excursion to Alipurduar district revealed the presence of corticolous Thysananthus repletus with the presence of gemmae on leaf lobe as well as on androecial and gynoecial branches. This constitutes first report of occurrence of the species from the state of West Bengal. Here it is described to facilitate its identification and key to the Indian species of the subgenus.

\section{Materials and Methods}

Different morphological features of the specimen were studied and photographed under bright field biological research microscope (Olympus CX41) and Stereo zoom binocular microscope (Olympus VT- II). The specimen has been carefully studied and compared with relevant literature records and herbarium specimen. The specimen can be distinguished from the literature record that is

(C) Singh Deo (2020). This is an open-access article distributed under the terms of the Creative Commons Attribution License, which permits unrestricted use, distribution, and reproduction in any medium, provided the original author and source are credited (https://creativecommons.org/licenses/by/4.0/).

To cite this article: Singh Deo S. A note on Thysananthus repletus (Lejeuneaceae: Marchantiophyta) with new report on asexual reproduction. Plant Science Today. 2020;7(3):349-352. https://doi.org/10.14719/pst.2020.7.3.728 
available on several accounts as discussed in details later.

\section{Taxonomic Description and Discussion}

Thysananthus repletus (Taylor) Sukkharak \& Gradstein, Phytotaxa 326 (2): 103. 2017. Lejeunea repleta Taylor, London J. Bot. 5: 392. 1846. Mastigolejeunea repleta (Taylor) A. Evans, Mem. Torrey Bot. Club 8 (2): 131. 1902. (Fig. 1: 1-17).

Plants blackish green when fresh, black to brownish-black in herbarium; shoots 8-30 mm long, 1.8-3.0 mm wide including leaves; branching Lejeunea-type, branches pinnate, throughout the plant, forming dendroid habit or not, flagelliform branches seen in older portion of stem. Stem subcircular in outline in transverse section, 212-220 × 185-220 $\mu \mathrm{m}, 9-10$ cells across the diameter, dorsal cortical cells larger than medullary and ventral cortical cells, 14-20 × 16-24 (-40) $\mu \mathrm{m}$, ventral cortical cells $10-18 \times 12-16 \mu \mathrm{m}$, thick-walled, yellowishbrown; medullary cells 8-16 × 10-18 $\mu \mathrm{m}$, thickwalled, yellowish-brown. Rhizoids few, in older portion of shoot. Leaves fragile, imbricate, obliquely spreading, weakly convex; leaf lobe ovate - oblongovate, $1.0-1.35 \mathrm{~mm}$ long, $0.72-0.90 \mathrm{~mm}$ wide, 1.35-1.6 as long as wide, apex acute - obtuse, margins entire, dorsal margin plane - wavy, occasionally cordate at base, ventral margin revolute; apical-marginal leaf cells $8-20 \times 6-12 \mu \mathrm{m}$; median leaf cells $14-24 \times 8-10$ $\mu \mathrm{m}$; basal leaf cells $24-40 \times 16-20 \mu \mathrm{m}$; walls thin with cordate trigones, intermediate thickenings $0-2$, prominent in basal cells; surface smooth; oil-bodies not seen; leaf lobule $1 / 3-1 / 4$ as long as the leaf lobe, rectangulate, $0.43-0.53 \mathrm{~mm}$ long, $0.21-0.25 \mathrm{~mm}$ wide, margin truncate to oblique, terminating at the end of the keel or continuing into the ventral lobe margin; teeth $0-3$, blunt, 1-3 cells long, 1-4 cells wide at base; keel nearly straight, smooth. Under leaves imbricate, 3-4 times as wide as the stem, squarrose - spathulate, 0.56-0.67 mm long, $0.79-0.83 \mathrm{~mm}$ wide, apex truncate - emarginate, wavy, nearly entire, lateral margins entire, bases free, cuneate or slightly auriculate. Asexual reproduction by discoid gemmae, present on the dorsal surface and on apical margin of leaf lobe, occasionally on male and female bracts as well as on perianth.

Autoicous. Androecia terminal or intercalary; bracts in 8-16 series; bracteoles present throughout the androecium. Gynoecia terminal on main shoot with 1-2 subfloral innovation; bract lobe ovate, 1.1$1.4 \mathrm{~mm}$ long, 0.6-0.8 $\mathrm{mm}$ wide, apex acute apiculate; lobule ovate-oblong, $1 / 2-3 / 5$ of lobe length, apex truncate; bracteole elongate, spathulate, 0.8-1.1 $\mathrm{mm}$ long, 0.7-0.8 mm wide, apex truncate, margins smooth, recurved. Perianths cylindrical, $1.4-2.0 \mathrm{~mm}$ long, 0.7-0.9 mm wide at middle, 3-keeled, keels smooth; beak 2-4 cells long. Mature sporophyte not seen.

Habitat: Corticolous, growing on the tree trunks in subtropical forests in cold and dry conditions.

Distribution: India [Eastern Himalaya (West Bengal present study, Arunachal Pradesh, Assam, Meghalaya, Sikkim), Western Himalaya (Uttarakhand), Western Ghats (Kerala, Tamil Nadu),
Andaman \& Nicobar Islands (Andaman Islands, Nicobar Islands) $[(1,2,3,4,5,6,7)$ all as $M$. repleta)], Bhutan (8), China (9), French Polynesia (10), Indonesia (10), Japan (10), Malaysia (11), Nepal (12), New Caledonia (10), Papua New Guinea (13), Philippines (14), Samoa (15), Solomon Is. (10), Sri Lanka (16), Taiwan (17), Thailand (18), Vietnam (10), Australia (10) all as $M$. repleta.

Specimens examined: India - Eastern Himalaya, West Bengal, Alipurduar district, Shalkumar forest, near Torsha Rhino camp, ca 90 m, 30.11.2018, S. Singh Deo 001/2019 (CAL); Jayanti, Buxa Tiger Reserve, ca 90 m, 24.01.2019, S. Singh Deo 002/2019 (CAL).

Note: Thysananthus repletus is characterized by robust plants, $1.8-3.0 \mathrm{~mm}$ wide including leaves (Fig. 1: 1-3); stem dorsal cortical cells larger than medullary and ventral cortical cells (Fig. 1: 4); ovate oblong-ovate leaf lobes with acute - obtuse apex with entire margins (Fig. 1: 5-8); leaf lobule, 1/3-1/4 as long as the lobe with teeth $0-3$ teeth, teeth $1-3$ cells long, 1-4 cells wide at base (Fig. 1: 5-8, 11, 12); female bracts with acute - apiculate apex (Fig. 1: 16); perianth 3-keeled, keels smooth (Fig. 1: 15).

Key to Indian species of Thysananthus subg. Mastigolejeunea

1a. Leaf dorsal lobe narrowly oblong, about twice as long as wide, leaf lobule about $1 / 9-1 / 4$ of dorsal lobe length T. ligulata

1b. Leaf dorsal lobe ovate, oblong-ovate or ovatetriangular, 1.35-1.6 times as long as wide, leaf lobule $1 / 3-1 / 4$ or $1 / 2$ of dorsal lobe length .......................................................... 2

2a. Leaf lobule $1 / 2$ as long as leaf lobe........ T. indica

2b. Leaf lobule $1 / 3-1 / 4$ as long as leaf lobe 3

3a. Leaf lobule apex with a single, long, narrow, uniseriate tooth, 3-7 cells long ............. T. virens

3b. Leaf lobule apex with a 0-3 short teeth, 1-3 cells long, 1-4 cells wide at base .. 4

4a. Shoots $1.8-3.0 \mathrm{~mm}$ wide including leaves; leaf lobe apex acute - obtuse T. repletus

4b. Shoots 1-2 mm wide including leaves; leaf lobe apex rounded - obtuse T. humilis

\section{Discussion}

$T$. repletus resembles $T$. humilis in general appearance, leaf shape, size and leaf lobule size. However, differs in smaller plants (1-2 mm wide including leaves) and rounded to obtuse leaf lobe apices in the latter (10). However, leaf lobe apices remain variable for both the species with acute obtuse found in both the population reported here. Rounded, obtuse, acute or acuminate leaf lobe apices have been reported for the latter species as well (5, 19). Two species are differentiated based on presence of accessory plicae on the 3-plicate perianth of the latter species as against absence of any additional fold in the former (5). However, there are reports on the presence of trigonous perianths without supplementary folds in the latter species (10). 


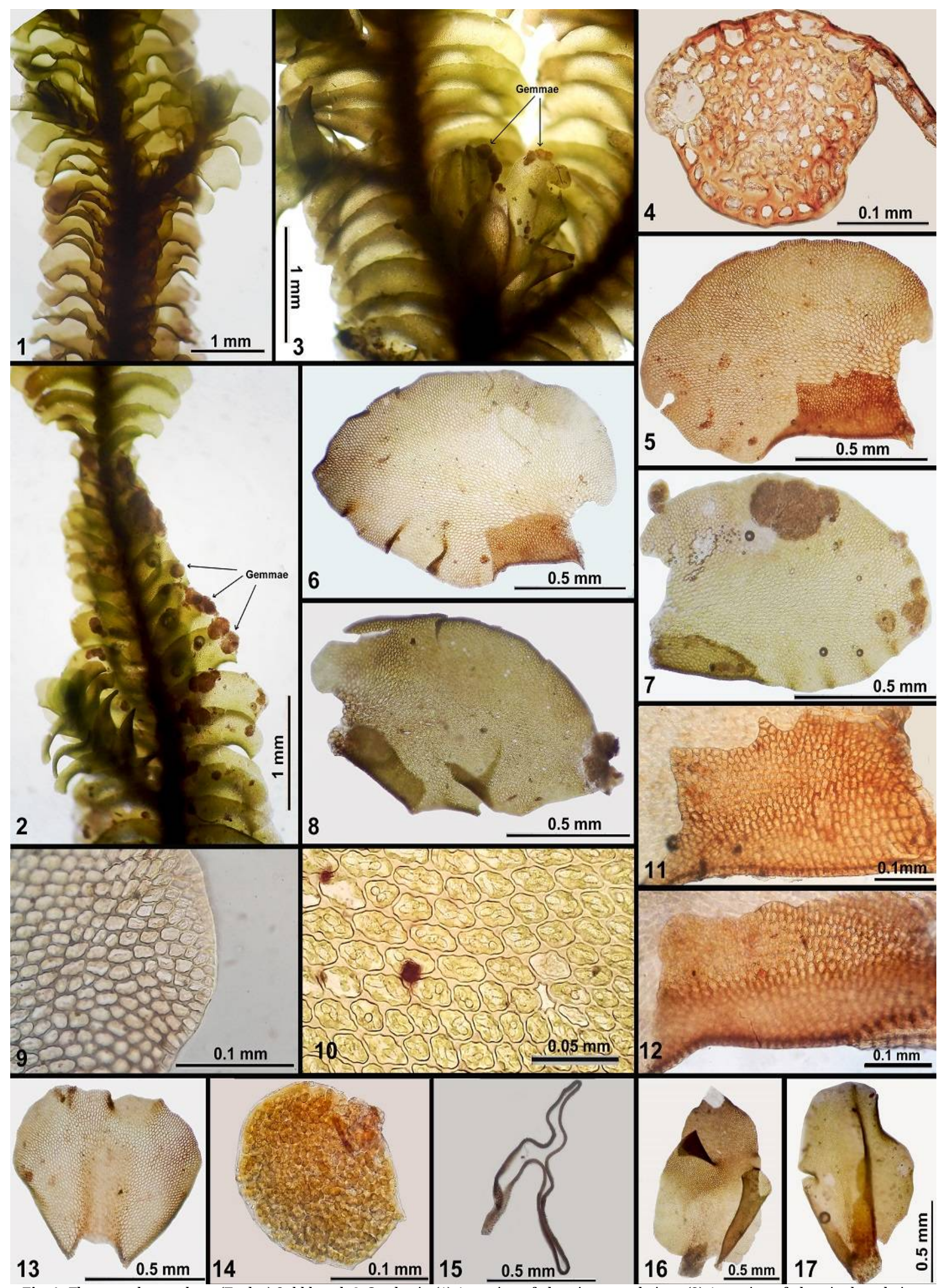

Fig. 1. Thysananthus repletus (Taylor) Sukkharak \& Gradstein (1) A portion of plant in ventral view. (2) A portion of plant in dorsal view showing androecial branch. (3) A portion of plant in dorsal view showing gynoecial branch. (4) Transverse section of the stem. $(5,6)$ Leaves. $(7,8)$ Leaves, bearing gemmae. (9) Apical leaf cells. (10) Median leaf cells. $(11,12)$ Leaf lobules. (13) An underleaf. (14) A gemmae. (15) Transverse section of perianth. (16) A female bract. (17) A female bracteole (micrograph 2,3,7,8,12,14 from S. Singh Deo 002/2019, others from S. Singh Deo 001/2019). 
Asexual reproduction is rare for the genus with only a few previous reports for T. auriculatus (Wilson \& Hook.) Sukkharak \& Gradst (20). The T. repletus specimen from Jayanti shows abundant discoid gemmae, present on the dorsal surface of leaf lobe and apical margin of leaf lobe, and occasionally on male and female bracts as well as on perianth. The specimen from Shalkumar forest have occasional occurrence of such gemmae. This constitutes the first report of asexual reproduction for the species.

\section{Competing interests}

Author do not have any competing interests.

\section{Acknowledgements}

I thank the Principal, Banwarilal Bhalotia College for providing facilities and financial assistance for field trip, Dr. Phiangphak Sukkharak, Burapha University, Thailand and Dr. Anders Hagborg, Field Museum, Chicago, USA for relevant help.

\section{References}

1. Sukkharak P, Gradstein SR. Phylogenetic study of Mastigolejeunea (Marchantiophyta: Lejeuneaceae) and an amended circumscription of the genus Thysananthus. Phytotaxa. 2017;326: 91-107. https://doi.org/10.11646/phytotaxa.326.2.1

2. Singh DK, Singh SK, Singh D. Liverworts and Hornworts of India - An Annotated Checklist. Kolkata: Botanical Survey of India; 2016

3. Mitten W. Hepaticae Indiae Orientalis, An enumeration of the Hepaticae of East Indies. J Proc Linn Soc, Bot. 1861;5:89-128. https://doi.org/10.1111/j.1095-8312.1861.tb01343.x

4. Chopra RS. Notes on Indian Hepatics II. Sikkim Himalaya and Bengal. Proc Indian Acad Sci. 1938;8B:427-39

5. Awasthi US, Udar R. The genus Mastigolejeunea (Spruce) Schiffn. in India. Proc Indian Acad Sci, Pl Sci. 1984;93:485-94

6. Singh DK. Hepaticae (Bryophyta). In: Hajra PK, editors. A contribution to the Flora of Namdapha, Arunachal Pradesh. New Delhi: Botanical Survey of India; 1996. pp. 46-67
7. Daniels AED. Checklist of the bryophytes of Tamil Nadu, India Arch Bryol. 2010;65:1-117

8. Long DG, Grolle R. Hepaticae of Bhutan II. J Hattori Bot Lab. 1990;68:381-440

9. Zhu R-L. New checklist of Chinese liverworts, hornworts, and takakiophytes [Internet]. 2006. Available from: https://www.yumpu.com/it/document/view/4359880/new-checklist-ofchinese-liverworts-hornworts-and-takakiophytes

10. Sukkharak P, Gradstein SR. A taxonomic revision of the genus Mastigolejeunea (Marchantiophyta: Lejeuneaceae). Nova Hedwigia. 2014;99:279-345. https://doi.org/10.1127/0029$5035 / 2014 / 0206$

11. Chuah-Petiot M. A checklist of Hepaticae and Anthocerotae of Malaysia. Polish Bot J. 2011;56:1-44

12. Pradhan N, Joshi SD. Liverworts and hornworts of Nepal: a synopsis. Botanica Orientalis 2009;6:69-75. https://doi.org/ 10.3126/botor.v6i0.2913

13. Gradstein SR, He X-L, Piippo S, Mizutani M. Bryophyte flora of the Huon Peninsula, Papua New Guinea. LXVIII. Lejeuneaceae subfamily Ptychanthoideae (Hepaticae). Acta Bot Fenn. 2002; 174:1-88

14. Tan BC, Engel JJ. An annotated checklist of Philippine Hepaticae. J. Hattori Bot Lab. 1986;60:283-355

15. Grolle R, Schultze-Motel W. Vorlaufiges erzeichnis der lebermoose von Somoa. J Hattori Bot Lab. 1972;36:75-89

16. Long DG, Rubasinghe SCK. Liverworts and hornworts of Sri Lanka: a revised checklist. Ceylon J Sci, Biol Sci. 2014;43:1-36. https://doi.org/10.4038/cjsbs.v43i1.7280

17. Wang J, Lai M-J, Zhu R-L. Liverworts and hornworts of Taiwan an updated checklist and floristic accounts. Ann Bot Fenn. 2011;48:369-95. https://doi.org/10.5735/085.048.0501

18. Lai MJ, Zhu RL, Chantanaorrapint S. Liverworts and hornworts of Thailand: an updated checklist and bryofloristic accounts. Ann Bot Fenn. 2008;45:321-41. https://doi.org/ $10.5735 / 085.045 .0501$

19. Verma PK, Rawat KK, Yadav A, Kaushik PK. Mastigolejeunea humilis (Gott.) Schiffn. from Sibsagar, Assam, new to IndoBurma Biodiversity Hotspot. Geophytology. 2013;43:163-66

20. Fulford M. Sporelings and vegetative reproductive structures in Mastigolejeunea auriculata. Am J Bot. 1942;29:848-50. https://doi.org/10.1002/j.1537-2197.1942.tb10291.x 